\title{
THE SEMANTIC REPRESENTATION OF POSSESSEED-RAISING CONSTRUCTIONS IN TERMS REFLEXIVITY ${ }^{1}$
}

\author{
Beatriz Martínez Fernández \\ University of La Rioja
}

\begin{abstract}
This paper aims to provide arguments in favour of the widely discussed idea that English causative alternating constructions of the type "John broke his arm/His arm broke" are, at least partly, reflexive. As we shall see, several constraints condition this proposal, namely the actor/non-actor category of the first argument of the activity predicate and the concept of control. In addition, I will argue that the recurrent association of this particular causative formal composition to the above mentioned reflexive meaning leads us to consider this alternation as a new construction within the wider scope of causatives. This construction has been labelled as the Possessed-Raising construction.
\end{abstract}

\section{INTRODUCTION}

The idea that causative alternating constructions are partly reflexive is not new ${ }^{2}$. Many authors, including Siewierska (1990), Moreno Cabrera (1994), Van Valin \& LaPolla (1997) and Levin \& Rappaport Hovav (1995), among others, acknowledge the reflexive character of causative alternations of the type

(1) John broke his arm/his arm broke

1. Financial support for this research has been provided by Consejería de Juventud, Cultura y Deportes, Government of La Rioja and DGES, grant no. PB96-0520.

2. Causative alternations involve verbs with transitive and intransitive uses, where the transitive use of a verb $V$ can be paraphrased as roughly "cause to V-intransitive" (Levin, 1993: 27). 
in languages such as Italian or Spanish, where this reflexivity is syntactically marked by a clitic, namely si and se, respectively. However, all of them fail to assign this interpretation to their English equivalent, where no syntactic marker reveals any trace of a possible reflexive interpretation. By following the theoretical framework of Role and Reference Grammar, as rendered by Van Valin \& LaPolla (1997), I aim to prove the reflexive character of causative alternations in English and, more specifically, to define the circumstances that license that reading. As a conclusion, I propose a construction called Possessed-Raising, which I characterise from the morphological, syntactic, semantic and pragmatic points of view.

Siewierska (1990), Moreno Cabrera (1994), Levin \& Rappaport Hovav (1995) and Van Valin \& LaPolla (1997) agree on the idea that it is possible to give a unified account of reflexive and causative alternating constructions in languages where one and the same clitic is used in both contexts. In these languages, the intransitive variant of the causative alternation is derived from the transitive one by means of a process of valency reduction through which, using Van Valin \& LaPolla's (1997) terms, the bighest-ranking argument in the logical structure (LS), that is to say, the subject in English, is suppressed. As a consequence, as Siewierska (1990: 5) points out, the transitive action predicate is transformed into a process predicate where the transitive goal (or Undergoer), in Van Valin \& LaPolla's (1997) terms) becomes the syntactic subject (that is, the Privileged Syntactic Argument) of the new predicate, and the reflexive clitic makes its appearance. Example (2) illustrates this point.

(2) Italian (from Van Valin \& LaPolla 1997:409)

Maria ha aperto la finestra "Maria oponed the window"

La finestra si è aperta "The window opened"

Some languages, like Spanish, reveal this clitic not only in the intransitive version, but also in the transitive, at least with certain verb classes such as Levin's (1993) break group. See example (3) for illustration.

(3) Spanish

María se fracturó el brazo "Mary fractured her arm"

Su brazo se fracturó/Se fracturó el brazo "Her arm fractured"

The problem lies in the fact that none of these authors defines the circumstances that surround this phenomenon, that is, the factors that determine the reflexive/non-reflexive reading of these constructions, neither do they delimit the kind of verbs that participate in it. Thus, on a provisional basis, and taking example (3) as a point of departure, I make the following proposals: 
1. The constructions in focus differ from other alternating causative constructions in several respects:

1.1. Their arguments are in a relationship of inalienable possession. ${ }^{3}$

1.2. Their highest-ranking argument is animate in their transitive variant.

1.3. In many languages, they have a reflexive clitic like $s i$ in Italian or se in Spanish which supports the plausibility of a reflexive reading under specific circumstances.

Therefore, a different analysis is required which accounts for the presence/absence of reflexivity in their different realisations.

2. Taking Levin's (1993) work on the existing variety of English verb classes and alternations as a point of reference, I define the verbal class participating in this alternation as the group of verbs of pure-change-of-state whose members are in a relationship of inalienable possession, and whose highest-ranking argument is animate; e.g. crack in (4).

(4) The wind was strong and bitterly cold as we prepared ourselves and I tried in vain to put my boots on without leaving the car, until I cracked my forehead on someone's ice-axe in the back seat.

In the remainder of this paper I intend to offer a plausible account of English causative alternating constructions within the framework of RRG, capturing the fundamental factors that determine their reflexive condition.

\section{REFLEXIVE INTERPRETATION OF CAUSATIVE ALTERNATING CONSTRUCTIONS}

\subsection{Transitive variant}

As I have said in the introduction, English causative constructions lack a syntactic marker like the Italian si or the Spanish se that signals any trace of reflexivity. Nonetheless, the English alternation seems to present the same semantic characteristics as the latter. Accordingly, it should be possible to portray these pairs in the same way as their Spanish or Italian equivalents, that

3. I use this term after Van Valin \& LaPolla (1997: 190), who define it as involving a partwhole relation between the possessor and the possessed, e.g. a table and its legs, a bird and its wings, a car and its wheels. For an explanation of the part-whole metonymy see Kövecses \& Günter (1998), Ruiz de Mendoza (1999) and Martín Arista (2001). 
is to say, as reflexive constructions ${ }^{4}$. Let us begin by analysing the transitive causative variant of the alternation. I take examples (5) and (6) for illustration.

(5) English: John fractured his arm

(6) Spanish: Juan se fracturó el brazo "John fractured his arm"

Following Van Valin \& LaPolla (1997), the syntax/semantics interface of causative constructions can be described as follows in (7) and (8),

(7) Semantic Representation/Logical Structure (LS):

[do'(x, Ø)] CAUSE [BECOME predicate'(y)]

(8) Linking:

Transitivity: 2 Macroroles/MRs (Actor and Undergoer)

which applied to the examples mentioned above results into in (9) and (10), respectively:

(9) English: John fractured his arm

LS: [do'(John, Ø)] CAUSE [BECOME fractured'(have.as.part'(John, $\underline{\text { arm })}$ ] Linking: Actor-John; Undergoer- arm

(10) Spanish: Juan se fracturó el brazo

LS: [do'(Juan, Ø)] CAUSE [BECOME fractured'(have.as.part'(Juan, $\underline{\operatorname{brazo}})]$

Linking: Actor-Juan; Undergoer- brazo

In Spanish, the reflexive character of the construction can be derived from the presence of the clitic se. However, it must be noted that Juan se fracturó el brazo does not always conform to a reflexive interpretation; it depends on the context. Example (11) illustrates this idea.

(11) Juan se fracturó el brazo en el accidente "accidentally" (event interpretation)

(12) Juan se fracturó el brazo para ganar la apuesta "intentionally" (action interpretation)

4. That is to say, as an association of a certain formal structure (John fractured his $\mathrm{arm} / \mathrm{his}$ arm fractured) with a meaning specification (reflexive meaning) which shall be specified in terms of semantic roles, macroroles and co-referentiality in this and forthcoming sections. 
Therefore, the question at issue is, when does the reflexive reading apply? The sentence in (11) does not reveal a reflexive interpretation. It describes an event where the clitic se signals that, despite having a proper Undergoer ( $\mathrm{el}$ brazo), the participant Juan also receives the results of the action through metonymic extension, but he does not perform the action himself; it is an accident. Accordingly, there is no agency implied on the part of Juan. Sentence (12), by contrast, allows for a reflexive interpretation, for Juan is an agentive participant who performs and, at the same time, undergoes, the action. It logically follows that there is a close relationship between agency and reflexivity. But this statement is not accurate enough, for the agent might not have performed the action purposefully, yet he would still be considered as doer and receiver simultaneously. Let us imagine that John is driving some nails in the wall at home and, accidentally, hits his arm with the hammer and breaks it. John did not break his arm on purpose, however he is the doer and -through metonymic extension- undergoer of the action. In such a context, a sentence like John broke his arm renders a reflexive reading. Thus, the statement above can be rephrased as follows: actorbood allows for reflexivity, whereas -in the context of this work- non-actorbood blocks it.

This opposition between reflexive/non-reflexive readings is, nevertheless, not observed in the semantic representation of the constructions, which are linked to the same logical structure. Thus, the problem lies in how to capture this difference in terms of semantic representation. As regards non-reflexive patterns, John cannot be an ACTOR 5 , from which it follows that this argument cannot be placed in the activiy predicate (we will discuss this in section III). For those cases following a reflexive pattern the solution is straightforward. Van Valin \& LaPolla (1997: 119) state that the logical structure for verbs which lexicalize agency is one of the type in (13),

(13) DO (x, [do' $(x,[\ldots$

where $\mathrm{x}$ is the agent, and they emphasise the fact that this structure applies only to those activity predicates whose argument must be an agent. For those predicates which have an effector instead of an agent, the logical structure is one of the type in (14), where $\mathrm{x}$ is the effector ${ }^{6}$.

5. Microroles and Macroroles shall be written in capital letters when subscribing to the RRG paradigm, whereas they shall appear in small letters when used in a more general sense.

6. According to Van Valin and LaPolla (1997: 85), the participant role agent is defined as a willful, purposeful instigator of an action or event, whereas the effector is to be interpreted as the doer of an action, which may or may not be wilful or purposeful. 
(14) do' $(x, \ldots$

Therefore, the logical structure for example (12) is as displayed in (15):

(15) DO (Juan,[do'(Juan, Ø)] CAUSE [BECOME fractured'(have.as.part' (Juan, $\underline{\text { brazo}}))]$ )

As I have already remarked, the Spanish example poses no serious problem, for its reflexive reading is marked by the presence of the clitic se. English, by contrast, lacks any syntactic marker that points to a reflexive interpretation in causative constructions. Nonetheless, the very same opposition between the actor/non-actor reading of the first argument of their transitive variant can be found in both languages. Examples (16) and (17) illustrate this opposition in English:

(16) John fractured his arm in the accident. "accidentally" (event interpretation)

(16) John fractured his arm to get the money from the insurance. "intentionally" (action interpretation)

In other words, English causative constructions can be found in the same contexts as their Spanish equivalents with se, from which I presume that a unified account can be given in both languages. The logical structure for example (17) is displayed in (18): arm)]

(18) DO [do'(John, Ø)] CAUSE [BECOME fractured'(have.as.part'(John,

To sum up, it should be kept in mind that the reflexive character of transitive causative constructions is conditioned by the actor/non-actor role of the first argument of the activity predicate.

\subsection{Intransitive variant}

As I have mentioned before, Siewierska (1990: 5) acknowledges the reflexive character of inchoative predicates, which she includes within the wider group of pseudo-reflexives. She describes them as intransitive predicates derived from their transitive variants by means of a valency reduction rule, this change being signalled by the presence of a reduction marker in many languages. Similarly, Van Valin \& LaPolla (1997: 243) interpret the intransitive member of the causative predicate as the result of a process of detransitivization through which the highest-ranking argument in the logical structure is suppressed. The transitive goal or Undergoer becomes then the privileged syntactic argument, leading to a valency reduction in the new predicate. 
As I see it, however, this predicate is not just a mere derivation of a transitive counterpart, but a systematic association between form and meaning; that is to say, a construction? ${ }^{7}$. Illustration is provided in (19):

(19) The child cracked his head when he fell down.

His head cracked when he fell down.

The possessed argument, his head, is displaced -using this term after Dik (1997: 436) - from the second argument position to the highest-ranking argument position, leaving out the former one, that is, the child. This displacement yields the interpretation of a raising phenomenon. Therefore, henceforth I shall refer to this construction as the Possessed-Raising construction ${ }^{8}$.

Again, I start off from the intuition that, in Spanish, Possessed-Raising constructions may have a reflexive reading signalled by the reflexive marker se. What circumstances condition that reading? Let us examine the following example:

Su pierna se fracturó. "His leg fractured (by itself)"

The marker se can have two readings: it can be an impersonal se, indicating that the cause of the fracture is unknown, or it can have a reflexive reading, meaning by itself. If we focus on the latter, the reflexive marker must denote not only that the privileged syntactic argument receives the consequences of the action expressed by the verb, but also that there is no external cause to the predicate. Therefore, the action must have been internally caused. Consequently, the question is: is it possible to explain such an event in terms of internal causation? Let us go back to example (20): if the action were caused by the decalcification of the bones, it might be said that it is the inherent properties of the leg that are responsible for bringing about the fracturing. Therefore, there is some kind of actorhood implied on the part of the leg, which can then be said to merge both the Actor and Undergoer Macroroles, allowing for a reflexive reading. This might seem to be in contradiction with Levin and Rappaport Hovav's (1995: 93) assumption that

Some externally caused verbs such as break can be used intransitively without the expression of an external cause, but, even when no cause is specified, our knowledge of the world tells us that the eventuality these verbs describe could not have happened without an external cause. We thus assume that the intransitive verbs that regularly have transitive

7. I refer the reader to Bloomfield (1933) and Goldberg (1995) for this definition of construction.

8. I prefer the term raising instead of matrix-coding, as in Van Valin \& LaPolla 1997, because this is the generally accepted term in the literature. 
causative uses are externally caused, and those intransitive verbs that do not are internally caused.

However, there lies the explanation for my proposal: it is our knowledge of the world that tells us that the verbs under study here do not behave exactly like the others belonging in the same group of pure-change-of-state verbs. Even if apparently similar, our knowledge of the world tells us that it is not the same to say

(21) a. John broke the window (prototypical actor $=\mathrm{DO} / \mathbf{d o}$ ')

b. The window broke

than

(22) a. John broke his arm (non-prototypical actor)

b. His arm broke

for whereas in (21.a) John is clearly an actor and, in (21.b), there is a high probability for the existence of an external -although non-explicit- actor, the actor role of John in (22.a) is not so clear, for people do not usually fracture their arms on purpose or by themselves. There is usually an external actor that causes the breaking. However, this paper aims, among other things, to prove that these verbs, under certain circumstances, allow for such a reading, and this is due to the reflexive component concealed by these constructions. Were it not for the explicit marker present in other languages, this fact could have gone completely unnoticed, but fortunately contrastive studies make it possible to take notice of otherwise unnoticeable phenomena in other languages.

According to Levin \& Rappaport Hovav (1995), the opposition between internal and external causation is signalled in the semantic representation by the presence or absence of the activity predicate. Thus, the semantic representation for externally caused predicates is as shown in (23),

\section{(23) [[x DO-SOMETHING]CAUSE [y BECOME STATE]]}

and that for internally caused predicates is illustrated in (24).

\section{[X PREDICATE]}

The problem lies in the fact that the logical structure in (24) does not yield a reflexive reading per se. This structure could correspond, for instance, to a context where a football player is hit by the ball and, as a result, his arm is broken. Therefore, a different reflexive marker must be introduced within this frame to avoid ambiguities. Moreno Cabrera (1994), in his verbal reflexive marking proposal, puts forward the use of a morphological marker, [Rfx], in 
the predicate which signals that the transitive predicate is reflexively applied to its only argument. On these foundations, the logical structure for (22.b) -along the lines of the RRG semantic apparatus- is as follows in (25):

\section{(25) BECOME broken' ${ }_{[\mathrm{Rfx}]}$ (have.as.part' (3sg, arm)}

Finally, since I have argued that Possessed-Raising is a construction, I put forward the following constructional template, which offers a complete characterisation of the construction from multiple perspectives.

\begin{tabular}{|c|}
\hline $\begin{array}{l}\text { CONSTRUCTION } \\
\text { Possessed-raising construction with verbs of pure-change-of-state }\end{array}$ \\
\hline $\begin{array}{l}\text { SYNTAX } \\
\text { Template(s): accomplishment/achievement } \\
\text { PSA: non-human Undergoer } \\
\text { No pragmatic pivot (no passive) }\end{array}$ \\
\hline $\begin{array}{l}\text { MORPHOLOGY } \\
\text { No explicit reflexive morphology } \\
\text { Alternation Agent/Effector/Patient }\end{array}$ \\
\hline $\begin{array}{l}\text { SEMANTICS } \\
\text { Actor and reflexive pronoun are obligatorily co-referential }\end{array}$ \\
\hline $\begin{array}{l}\text { PRAGMATICS } \\
\text { Potential Focus Domain: Clause } \\
\text { Actual Focus Domain: (prototypically) Possessed }\end{array}$ \\
\hline
\end{tabular}

Constructional template for possessed-raising constructions with verbs of pure-change-ofstate in English

\section{NON-REFLEXIVE INTERPRETATION OF CAUSATIVE ALTERNATING CONSTRUCTIONS}

Levin \& Rappaport Hovav (1995: 82) assume that "the alternating unaccusative verbs 9 have a single lexical semantic representation associated with both their unaccusative and transitive forms, and that this is a causative lexical semantic representation". Taking into account that break verbs belong

9. Alternating unaccusative verbs are of two types: 1. Verbs participating in the causative/inchoative alternation, and 2. Verbs participating in the induced action alternation. See Levin (1995) for further detail. 
in this class, it follows that its members have a complex semantic representation with a CAUSE predicate for both their transitive and intransitive uses. The corresponding logical structure for break is displayed in (26),

\section{(26) Break: [[x DO-SOMETHING] CAUSE [y BECOME BROKEN]]}

which, by extension, can also be applied to all break verbs, namely, break, chip, crack, crash, crush, fracture, rip, shatter, smash, snap, splinter, split, and tear, (Levin 1993: 28), with the only difference that the lexical variant will change for each verb. Let us use as illustration the logical structure for fracture in (27),

(27) Fracture: [[x DO-SOMETHING] CAUSE [y BECOME FRACTURED]]

which, along the lines of Van Valin \& LaPolla (1997), is represented as shown in (28).

\section{(28) $\left[\mathbf{d o}^{\prime}(\mathrm{x}, \varnothing)\right]$ CAUSE [BECOME fractured'(y)]}

However, as we saw in section II.1., this logical structure does not satisfy the demands of examples like (29), which may have different interpretations.

(29) John fractured his arm

To recapitulate, in section II.1. it was argued that a statement like (29) may be interpreted, on the one hand, as an activity predicate where the participant John is an actor who performs and -licensed by the relationship of inalienable possession existing between its arguments- undergoes a certain action. Hence its reflexive reading. On the other hand, the same example gives rise to a more plausible unmarked event interpretation which presents John as a passive undergoer who suffers the consequences of an external action, thus preventing a reflexive reading ${ }^{10}$. This opposition between reflexive/nonreflexive readings is, nevertheless, not contemplated in the semantic representation of the constructions, which are linked to the same logical structure. Thus, the problem lies in how to capture this difference in terms of semantic representation. Reflexivity has already been dealt with in section II.1., so attention shall be paid hereafter to non-reflexive patterns. Let us look back at example (29). Granted the accidental character of the incident and John's

10. Markedness is to be understood here as described by Croft (1990). 
undergoer role, it is not possible to place this participant in the EFFECTOR position in logical structure. That would be incongruous, for the EFFECTOR is, quoting Van Valin \& LaPolla (1997: 85), "the doer of an action, which may or may not be wilful or purposeful", like Peter in (30):

(30) Peter broke the clock last year.

The unmarked interpretation of this example involves a certain type of action or manipulation from Peter on the clock, regardless of whether the result is brought about purposefully or not. In (29), by contrast, the default interpretation is different. Our knowledge of the world tells us that, in general, nobody grasps his/her own arm and breaks it. A sentence like (29) is usually understood as happening accidentally, for example, as a result of a blow received in a car accident. In that case, the first participant in the state of affairs (SoA), John, cannot be said to have performed any action that leads to the consequent breaking. Therefore, the logical structure proposed by Levin \& Rappaport Hovav (1995), which I display in (31), does not fit the characteristics of fracture in this context, for John would be endowed with effectorhood:

(31) [[John DO-SOMETHING] CAUSE [his arm BECOME FRACTURED]]

The same applies to Van Valin \& LaPolla's causative logical structure in (32),

(32) [do'(John,Ø)] CAUSE [BECOME fractured'(have.as.part'(John, $\underline{\operatorname{arm})]}$

where John would be represented as the EFFECTOR of the action bringing about the breaking, which is not the case here. Thus, the question is, how can John be inserted into the corresponding logical structure without being considered as effector?. As shown in (32), John and his arm stand in a relationship of inalienable possession; that is to say, there exists a part-whole relation between the possessor, John, and the possessed, his arm. As John cannot be placed in the CAUSE subevent, for this would lead to the erroneous EFFECTOR interpretation, it necessarily has to be placed within the achievement/accomplishment subevent. Thus, the new logical structure must place John in the second subevent. Taking into account the relationship existing between the two participants in the state of affairs, I propose the logical structure in (33) for John fractured his arm last year.

(33) Last year'[BECOME fractured'(have.as.part'(John, $\underline{\operatorname{arm}}$ )] 
This structure allows for the representation of both arguments, none of them being characterised as an ACTOR and the two being in a relationship of inalienable possession, which guarantees the right degree of affectedness for both of them (that is, arm is the highest ranking argument and, therefore, in competition with the other argument it is the one which definitely receives undergoerhood, although John is also a patient by metonymic extension). Thus, the CAUSE subevent is not involved in all causative alternations, as Levin \& Rappaport Hovav (1995) claim. However, this structure is, by default, the semantic representation for (34).

(34) John's arm fractured last year (genitive-intransitive interpretation)

Whilst this type of logical structure does not pose any problem for the intransitive pair of the causative alternation, i.e. His arm fractured last year, whose logical structure would be one of the type illustrated in (35),

\section{(35) Last year'[BECOME fractured'(have.as.part'(3sg,arm)]}

it does present certain inconveniences for the transitive counterpart. More precisely, it is necessary to find a means to signal which syntactic representation, whether the transitive or the genitive-intransitive, applies in each case. This problem might be overcome by introducing some new item, operator, or parameter in logical structure that distinguishes the two syntactic projections. However, the introduction of elements ad hoc is uneconomical from the theoretical point of view, the use of already-existing explicative elements of RRG being preferable. More specifically, this theory has at its disposal a system of grammatical relations which does not recognise the traditional notions of subject and object, but which acknowledges the existence of certain syntactic arguments which control verb agreement and cross-reference. They are called controllers. The controller in Jobn fractured his arm (accidentally) is John, whereas the controller in John's arm fractured is arm. Examples (36) and (37) illustrate this point.

(36) John fractures his arm/John and Peter fracture their arm

(37) John's arms fracture/John's arm fractures

Thus, the distinction between the two sentences can be established by specifying this feature, namely that the possessor is the controller, in their syntactic templates. The results are displayed in (38) and (39).

(38) Syntactic Template for John fractured his arm: 
CONSTRUCTION

Causative construction with arguments in a relationship of inalienable possession

\section{SYNTAX}

Template(s): accomplishment/achievement

PSA. Syntactic Pivot: non-human UNDERGOER. Controller: Possessor

No pragmatic pivot (no passive)

MORPHOLOGY

Unspecified $^{11}$

SEMANTICS

Possessor and Possessed are PATIENTS

\section{PRAGMATICS}

Potential Focus Domain: Clause

Actual Focus Domain: (prototypically) Possessed

Constructional template for Causative constructions with arguments in a relationship of inalienable possession in English

(39) Syntactic Template for John's arm fractured:

\begin{tabular}{|c|}
\hline $\begin{array}{l}\text { CONSTRUCTION } \\
\text { Genitive-Intransitive Causative construction }\end{array}$ \\
\hline $\begin{array}{l}\text { SYNTAX } \\
\text { Template(s): accomplishment/achievement } \\
\text { PSA. Syntactic Pivot: non-human UNDERGOER. Controller: Possessed } \\
\text { No pragmatic pivot (no passive) }\end{array}$ \\
\hline $\begin{array}{l}\text { MORPHOLOGY } \\
\text { Unspecified }\end{array}$ \\
\hline $\begin{array}{l}\text { SEMANTICS } \\
\text { Possessor and Possessed are PATIENTS }\end{array}$ \\
\hline $\begin{array}{l}\text { PRAGMATICS } \\
\text { Potential Focus Domain: Clause } \\
\text { Actual Focus Domain: (prototypically) Possessed }\end{array}$ \\
\hline
\end{tabular}

Constructional template for Genitive-Intransitive Causative constructions in English

11. I leave the morphology unspecified in both templates for there are several aspects like the role of the morpheme 'number' which deserve further attention. 
In summary, sentences with break verbs participating in causative alternations like John broke his leg/His leg broke can be considered to happen accidentally, John being simply a PATIENT. This interpretation does not allow for the traditional logical structure of the type [do' $(\mathrm{x}, \varnothing)$ ] CAUSE [BECOME broken'(y)], (Valin \& LaPolla (1997)), for this implies some kind of effectorhood on the part of the $\mathrm{x}$ argument, (which contradicts the accidental interpretation). Consequently, I propose a logical structure that represents both John and his leg as patients in a relationship of inalienable possession. As this logical structure is the same as that used for genitive-intransitive sentences like John's leg broke, I specify the feature "Controller = Possessor" in the syntactic template of the former to distinguish it from the latter, whose controller is the possessed element. The result is shown in (38) and (39). As regards the intransitive member of the alternation, there is no need to introduce any additional parameter, for the logical structure in terms of inalienable possession perfectly complies with the semantic and syntactic demands of the construction. Finally, it is noteworthy that the CAUSE subevent which is described by Levin \& Rappaport Hovav (1995) as an indispensable part of the semantic representation for verbs participating in the causative/inchoative alternation is not necessary when the accidental interpretation applies (for the secondary argument is represented in the CONSEQUENCE subevent of the logical structure). Therefore, the final logical structure is basically one of the type achievement/accomplishment whose participant arguments are in a relationship of inalienable possession; the subevent CAUSE shall only be added when explicitly specified in the sentence.

\section{CONCLUSION}

In this paper I have discussed the different variables that condition the reflexive character of some causative alternating constructions, namely the actor/non-actor category of the first argument of the activity predicate and the concept of control. Furthermore, I have argued that the many constraints that surround this reflexive reading define such a precise context where form and meaning recurrently match that this alternation should be regarded as a new construction within the wider scope of causatives. I have labelled it the Possessed-Raising construction.

Further research is needed, however, in order to provide a more elegant proposal that accounts for the whole array of interpretations displayed in one single lexical entry. 


\section{REFERENCES}

Bloomfield, L. 1933. Language. New York: Holt.

Croft, W. 1990. Typology and Universals. Cambridge: Cambridge University Press.

Dik, S. C. 1997. The Theory of Functional Grammar I : The Structure of the Clause. Dordrecht: Foris.

Goldberg, A. E. 1995. A Construction Grammar Approach to Argument Structure. Chicago: The University of Chicago Press.

Kövecses, Z. \& Radden, G. 1998. "Metonymy: Developing a cognitive linguistic view". Cognitive Linguistics 9 (1): 37-77.

Levin, B. 1993. English Verb Classes and Alternations. A Preliminary Investigation. Chicago: The University of Chicago Press.

Levin, B. \& Rappaport Hovav, M. 1995. Unaccusativity. At the SyntaxLexical Semantics Interface. Massachusetts: The MIT Press.

Martín Arista, F. J. 2001. "Adjustment and motivation". Revista Canaria de Estudios Ingleses 42: 167-186

Moreno Cabrera, J. C. 1991. Curso Universitario de Lingüistica General. Tomo I: Teoría de la gramática y sintaxis general. Madrid: Sintesis.

Ruiz de Mendoza Ibáñez, F. J. 1999. Introducción a la teoría cognitiva de la metonimia. Granada: Granada Lingvistica y Método Ediciones.

Siewierska, A. 1990. "The Source of the Dative Perspective in Polish pseudo-reflexives". Working with Functional Grammar: Descriptive and Computational Applications. Eds. Hannay \& Wester. Dordrecht: Foris. 1-14.

Van Valin, R. D. Jr. \& Lapolla, R.J. 1997. Syntax. Structure, meaning and function. Cambridge: Cambridge University Press. 